\title{
Hormonal contraception increases risk of breast tumor based on clinical breast examination among adult women
}

\author{
Sulistyowati Tuminah Darjoko* and Aprildah Nur Sapardin**
}

\begin{tabular}{l}
\hline \\
\hline *Center for Public Health Research \\
and Development \\
**Center for Health Resource and \\
Services Research and Development \\
Correspondence: \\
Sulistyowati Tuminah Darjoko \\
Center for Public Health Research \\
and Development \\
Jl. Percetakan Negara 29, \\
Jakarta Pusat \\
Email: sdarjoko@yahoo.com/ \\
watidarjoko@gmail.com
\end{tabular}

Date of first submission, May 26, 2017 Date of final revised submission, August 14, 2017

Date of acceptance, August 15, 2017

This open access article is distributed under a Creative Commons AttributionNon Commercial-Share Alike 4.0 International License

Cite this article as: Darjoko ST, Sapardin AN. Hormonal contraception increases risk of breast tumor based on clinical breast examination among adult women. Univ Med 2017;36:138-49. doi: 10.18051/UnivMed.2017.v36.138149

\section{BACKGROUND}

In Indonesia, cancer prevalence according to the Basic Health Research 2013 was 1.4 per 1000 inhabitants and the most common cancer in hospitalized patients in 2010 was breast cancer (28.7\%). Hormonal contraception (HC) use increases the breast cancer risk, even though HC has been used by 210 million women in the world. We aimed to define the association of $\mathrm{HC}$ with breast tumors based on clinical breast examination $(\mathrm{CBE})$.

\section{METHODS}

A case-control design using secondary data from the baseline of the Cohort Study on the Risk Factors of Non-Communicable Disease (RFNCD) in 2011-2012 in 5 villages in Central Bogor District, Bogor City. Samples consisted of 152 cases and 152 controls. Cases comprised palpable tumors in one or both breasts CBE (+). Controls had no tumors in both breasts / $\mathrm{CBE}(-)$. Data were analyzed by logistic regression.

\section{RESULTS}

Odds Ratio (OR) of CBE + was 1.83 (95\% CI: 1.11-3.04; $\mathrm{p}=0.019)$ for HC user and 1.62 (95\% CI: 1.01-2.60; $\mathrm{p}=0.044)$ for blood total cholesterol level $<200 \mathrm{mg} / \mathrm{dL}$. OR of group $\mathrm{CBE}(+)$ was 1.01 (current smokers) and 0.49 (former smokers) compared with nonsmokers $(\mathrm{p}=0.082)$; OR was also 1.21 for subjects with one child and 1.77 for those without children, compared with those who had $\geq 2$ children $(\mathrm{p}=0.454)$.

\section{CONCLUSION}

Hormonal contraception use increases breast tumor risk 1.8-fold after controlling for total cholesterol, smoking status and parity. With the several limitations of this advanced analysis, investigations focused on types and duration of $\mathrm{HC}$ use are still necessary.

Keywords: Hormonal contraception, breast tumor, adult women 


\section{INTRODUCTION}

Cancer is the principal cause of death in advanced countries and the second main cause of death in developing countries. ${ }^{(1)}$ Breast cancer is the most common cause of death from cancer in women (with 522,000 deaths in 2012) and is also the type of cancer occurring most frequently in women in 140 out of 184 countries. (2) The prevalence of cancer in Indonesia based on interview results in the Basic Health Research (Riskesdas) for 2013 was 1.4 per 1000 population and cancer was the seventh leading cause of death $(5.7 \%)$ from all-cause mortality. The most frequent type of cancer in hospitalized patients throughout Indonesia in 2010 was breast cancer $(28.7 \%) \cdot{ }^{(3)}$

The risk factors for breast cancer are among other things age, family history of breast cancer and reproductive factors characterized by exposure to sexual hormones (i.e. estrogen and progesterone in women). ${ }^{(4)}$ Both hormones are contained in hormonal contraceptives (HC). Oral contraceptives contain estrogen and progesterone, whereas the mini pills, contraceptive injections, and implants contain progesterone. ${ }^{(5,6)}$ The results of epidemiological and clinical research showed strong evidence on the role of estrogen/ progesterone in the formation of breast cancer, but the exact mechanism of tumor formation is not yet completely understood. ${ }^{(7,8)}$ According to Urban et al., ${ }^{(9)}$ there was an increased risk of breast cancer associated with the use of $\mathrm{HC}$, i.e. pills and/or injections ( $\mathrm{OR}=1.66 ; 95 \% \mathrm{CI}: 1.28$ 2.16; $\mathrm{p}<0.001)$, pills only $(\mathrm{OR}=1.57 ; 95 \% \mathrm{CI}$ : $1.03-2.40 ; \mathrm{p}=0.04)$, injections only $(\mathrm{OR}=1.83$; 95\% CI: $1.31-2.55 ; \mathrm{p}<0.001)$. The results of an analysis by Sihombing and Sapardin ${ }^{(10)}$ from data of the Cohort Study on Risk Factors of Noncommunicable Disease (RFNCD) [Studi Kohor Faktor Risiko Penyakit Tidak Menular (FRPTM)] showed that the use of contraceptive pills has a risk of 3.63-fold for causing tumors of the breast based on ultrasonography [USG] (95\% CI: $1.63-8.10 ; \mathrm{p}=0.002)$. This finding differs from that of an analysis by Sirait et al. ${ }^{(1)}$ from
Riskesdas 2007 data, who did not find a significant relationship between the use of contraceptive pills and tumor/cancer breast based on interviews $(\mathrm{aOR}=0.74 ; 95 \%$ CI: 0.50-1.08; $\mathrm{p}=0.117)$. In Indonesia, the percentages of $\mathrm{HC}$ users were: for injections $38.5 \%$, pills $31 \%$, and implants $12.3 \% .^{(10)}$

The novelty of this study lies in the diagnosis of breast tumors by means of clinical breast examination (CBE), because in the RFNCD cohort study the CBE results were a determinant for performing or not performing USG.

The reason for selecting CBE as a method of early detection is because the study by Zafar (12) showed that standardized CBE can differentiate between benign and malignant tumors. Structured CBE in patients with breast tumors has a sensitivity of $100 \%$ (95\% CI: 0.8 1) and a specificity of $94.6 \%$ (95\% CI: $0.86-$ 0.97 ) and the likelihood ratio for breast carcinoma is 17.8 (95\% CI: 7.6-41.7). The study by Ravi and Rodriguez ${ }^{(13)}$ found that among 15 cases of malignancy in patients who underwent mammography followed by histopathological confirmation, CBE detected one case of malignancy that had been overlooked in the mammogram. The research carried out by Khoda and Kapa ${ }^{(14)}$ in 50 female patients with clinically palpable breast lump(s) found on CBE, the lumps in $40(80 \%)$ patients had benign and $8(16 \%)$ had malignant features. However, $2(4 \%)$ patients were found to be in the "suspicious" category. On histopathological examination, 36 benign tumors were confirmed as such, but 4 were found to be malignant. All of 8 malignant tumors found by CBE were confirmed by histopathological examination. In the analysis of data from the previous RFNCD cohort study on tumors/cancers of the breast, ${ }^{(10)}$ there was no definition of the contraceptive pill variable, because in the questionnaire there was no specific question to differ between respondents who used one type of $\mathrm{HC}$ and those who used more than one type of $\mathrm{HC}$ (combined HC). Because of this limitation, $\mathrm{HC}$ as the main independent variable in the present paper was defined as contraception using pills or 
injections or implants. Results of several investigations showed that a higher total cholesterol concentration (TCC) has a decrease risk for tumors/cancers of the breast than a lower TCC. To determine the odds ratio of lower TCC $(<200 \mathrm{mg} / \mathrm{dL})$ against breast tumors, in this analysis high TCC $(\geq 200 \mathrm{mg} / \mathrm{dL})$ as another independent variable was positioned as a reference.

In Indonesia, data about breast tumors/ cancers are generally data from patients attending hospitals, who are usually already in an advanced stage. In 2016 the Indonesia Agency for Research and Development, Ministry of Health (Badan Penelitian dan Pengembangan Kesehatan) conducted a national research of noncommunicable disease that focused on breast tumors in the community, but the report is still in the process of finalization. According to Poosari et al. ${ }^{(15)}$, epidemiological research and risk factors for breast cancer are very important in its prevention. The use of $\mathrm{HC}$ is a risk factor for breast cancer, but the magnitude of the risk is not yet clear. Therefore, the aim of this further analysis was to determine the magnitude of the risk of $\mathrm{HC}$ use for the development of breast tumors based on $\mathrm{CBE}$.

\section{METHODS}

\section{Design of the study}

A case-control study was conducted using secondary data from the baseline of the RFNCD cohort study that had been performed in the years 2011-2012.

\section{Subjects}

The respondents were permanent residents aged 25-65 years in 5 kelurahan (villages) of Central Bogor District - Bogor City, i.e. Kebon Kalapa, Babakan Pasar, Babakan, Ciwaringin and Panaragan.The inclusion criterion was: female respondents who had already undergone CBE during the execution of the RFNCD cohort study and whose data were complete. The exclusion criterion was respondents who were pregnant or had been breastfeeding for equal or less than 6 months.

The 152 cases with positive CBE results $(\mathrm{CBE}(+))$ i.e. the presence of a tumor in one breast or both breasts, which were found in the RFNCD cohort study, were all included in the study sample. This number has met the minimum sample requirements which calculated with the formula of hypothesis testing for the odds ratio for case control studies, with a level of significance of $95 \%$ $(\alpha=5 \%)$ and power of $95 \%(\beta=5 \%)$. The OR that was considered to be significant was 3.6 and the estimated proportion effect in the controls was 0.657 , which was taken from the study results of Sihombing and Sapardin. ${ }^{(10)}$ The controls were respondents with negative $\mathrm{CBE}$ results i.e. no presence of a tumor in both breasts. The selection of the controls was performed in a ratio of 1:1 by simple random sampling, and they were not paired (unmatching), so that the analyzed data totalled 304 respondents, consisting of 152 cases and 152 controls. ${ }^{(16)}$

\section{Questionnaire}

The sociodemographic data that were collected as a result of the questionnaire-based interviews consisted of: 1$)$ age ( $<40$ years and $\geq 40$ years); ${ }^{(10)} 2$ ) education i.e. low (no formal education, not having finished elementary school, and finished elementary school), middle (junior high school and senior high school) and high (D3/ D4 and university); ${ }^{(17)} 3$ ) marital status i.e. have a partner (married) and have no partner (single or divorced/widowed). ${ }^{(15)}$ This grouping was used because there were very few respondents with single status, comprising only 10 subjects (3.3\%). Data about risk factors consisted of: 1 ) smoking status, i.e. nonsmoking (never smoked), former smoking (occasionally or daily) and current smoking (occasionally or daily);(18) 2 ) mental/emotional disorder was measured using the Self-Reporting Questionnaire instrument with 20 items of question (SRQ-20). The respondents were considered having a mental/emotional disorder if they answered "yes" to minimally 6 out of 20 questions in the instrument; ${ }^{(19)} 3$ ) parity/ 
number of deliveries was calculated from the total number of children that were born (own children), divided into 3 groups, i.e. "no children", "1 child" and " 2 children or more";(20) 4) breastfeeding experience i.e. "breastfeeding for $<6$ months or never did breastfeeding", and "breastfeeding for $\geq 6$ months"; ${ }^{(21)}$ 5) HC users (respondents who ever had sexual intercourse) were respondents who had ever used or were currently using contraceptive pills, injections or implants. The responses were divided into 2 categories, i.e. "yes" and "no". ${ }^{(15)}$ The use of hormone-replacement therapy (HRT) and consumption of hormonal medications (treatment for infertility) was not incorporated in this analysis since the data were very few in number. Regarding the foods/beverages that were habitually consumed, the respondents were asked according to the Food Frequency Questionnaire (FFQ); for example, consumption of milk, coconut milk, fried snacks and packaged beverages. Each type was divided into two categories, i.e. " $\geq 3$ times per week (frequent)" and " $<3$ times per week (seldom)". (22)

\section{Measurements}

Anthropometric measurement was performed according to the Guide to Examination and Measurement of the RFNCD cohort study (unpublished). The respondents were advised to use loose and thin clothing. Body weight (BW) was measured using AND type UC-322 digital scales with a capacity of $150 \mathrm{~kg}$ and precision of $50 \mathrm{~g}$. The respondents were asked to stand without footwear. Height was measured in the upright position using a "multifunction" measuring tool. The body mass index (BMI) was obtained by the following formula:

$$
\mathrm{BMI}=\mathrm{BW}(\mathrm{kg}) / \text { height }(\mathrm{m})^{2}
$$

Based on the classification of the South Asian Health Foundation, the BMI is divided into 4 categories, i.e. underweight (BMI $<18,5$ ), normal (18.5-22.9), overweight (23-24.9), obesity $(\geq 25) .{ }^{(23,24)}$ In the present analysis the BMI was only assigned into 2 categories, i.e. $\geq 25$ and $<25$. ${ }^{(10)}$

\section{Clinical breast examination}

In the CBE procedure, visual inspection and palpation was performed according to the Guide to Examination and Measurement of the RFNCD cohort study (unpublished). The CBE positive respondents were those who had a palpable tumor in one breast or both breasts (right/left). The CBE was performed by the midwife of the primary health care (puskesmas) who had been trained by a specialist in oncologic surgery from Dharmais Hospital - Jakarta.

\section{Laboratory blood analysis}

For the determination of blood lipid concentration, the respondents were asked to fast for 12-14 hours, from the night before the examination until the next morning. The respondents were only permitted to drink water. With the respondents in the fasting condition, venous blood samples were drawn from them. The lipid profile comprised TCC $(<200 \mathrm{mg} / \mathrm{dL}$ and $\geq 200 \mathrm{mg} / \mathrm{dL})$; triglycerides $(<150 \mathrm{mg} / \mathrm{dL}$ and $\geq 150 \mathrm{mg} / \mathrm{dL}$ ); low density lipoprotein cholesterol (LDL) $(<100 \mathrm{mg} / \mathrm{dL}$ and $\geq 100 \mathrm{mg} / \mathrm{dL})$; high density lipoprotein cholesterol (HDL) $(\geq 50 \mathrm{mg} /$ $\mathrm{dL}$ and $<50 \mathrm{mg} / \mathrm{dL}){ }^{(25)}$ Blood chemistry investigation was performed by Prodia Laboratory in Bogor City.

\section{Data analysis}

Bivariate analysis (chi-square test) was performed to determine the presence or absence of a difference in proportions between the dependent and independent variables, followed by multiple logistics regression analysis to determine the level of HC user risk for the presence of breast tumors based on CBE, by controlling for other variables. ${ }^{(26)}$

\section{Ethical clearance}

The RFNCD cohort study had already received ethical clearance from the Commission on Health Research Ethics of the Indonesia Agency for Research and Development, Ministry of Health (Badan Penelitian dan Pengembangan Kesehatan) under No. KE.01.08/EC/485/2011 
dated 10 August 2011 and No. KE.01.05/EC/394/ 2012 dated 11 May 2012.

\section{RESULTS}

Among the 2955 female respondents who underwent $\mathrm{CBE}$ in the RFNCD cohort study were found $152 \mathrm{CBE}(+)$ cases $(5.14 \%)$. The marital status of the majority of the respondents was "married/divorced/widowed" and only 10 (3.3\%) of the 304 persons were single. Among 231 contraceptive users, 184 persons (79.7\%) were current users or had ever used hormonal family planning, comprising 165 persons $(89.7 \%)$ with married marital status and 19 persons (10.3\%) with divorced marital status. Table 1 shows that more than half of the respondents, in both the $\mathrm{CBE}(+)$ and $\mathrm{CBE}(-)$ groups, were more than 40 years old, half of the $\mathrm{CBE}(+)$ group being of low educational level, with BMI of $<25$ and total cholesterol concentration (TCC) of $<200 \mathrm{mg} / \mathrm{dL}$. A large proportion of the $\mathrm{CBE}(+)$ group comprised respondents with triglyceride concentration of $<150 \mathrm{mg} / \mathrm{dL}, \mathrm{LDL} \geq 100 \mathrm{mg} / \mathrm{dL}$, and HDL $\geq 50 \mathrm{mg} / \mathrm{dL}$, who were not yet in menopause. While in the CBE(-) group, more than

Table 1. Characteristics of respondents based on positive and negative CBE

\begin{tabular}{|c|c|c|c|c|c|}
\hline \multirow{3}{*}{ Characteristic } & \multicolumn{4}{|c|}{ CBE } & \multirow{3}{*}{$p$ value } \\
\hline & \multicolumn{2}{|c|}{ Positive } & \multicolumn{2}{|c|}{ Negative } & \\
\hline & n & $\%$ & $\mathbf{n}$ & $\%$ & \\
\hline Age (years) & & & & & 0.340 \\
\hline$<40$ & 59 & 38.8 & 51 & 33.6 & \\
\hline$\geq 40$ & 93 & 61.2 & 101 & 66.4 & \\
\hline Education & & & & & 0.492 \\
\hline High & 11 & 7.2 & 11 & 7.2 & \\
\hline Middle & 78 & 51.3 & 68 & 44.7 & \\
\hline Low & 63 & 41.4 & 73 & 48.0 & \\
\hline Marital status & & & & & 0.882 \\
\hline Married & 124 & 81.6 & 125 & 82.2 & \\
\hline Single/divorced & 28 & 18.4 & 27 & 17.8 & \\
\hline BMI $\left(\mathrm{kg} / \mathrm{m}^{2}\right)$ & & & & & 0.038 \\
\hline$<25$ & 79 & 52.0 & 61 & 40.1 & \\
\hline$\geq 25$ & 73 & 48.0 & 91 & 59.9 & \\
\hline Total cholesterol $(\mathrm{mg} / \mathrm{dL})$ & & & & & 0.021 \\
\hline$\geq 200$ & 71 & 46.7 & 91 & 59.9 & \\
\hline ? 200 & 81 & 53.3 & 61 & 40.1 & \\
\hline Triglycerides (mg/dL) & & & & & 0.156 \\
\hline$\geq 150$ & 14 & 9.2 & 22 & 14.5 & \\
\hline$<150$ & 138 & 90.8 & 130 & 85.5 & \\
\hline LDL (mg/dL) & & & & & 0.216 \\
\hline$\geq 100$ & 123 & 80.9 & 131 & 86.2 & \\
\hline$<100$ & 29 & 19.1 & 21 & 13.8 & \\
\hline $\mathrm{HDL}(\mathrm{mg} / \mathrm{dL})$ & & & & & 0.720 \\
\hline$<50$ & 53 & 34.9 & 56 & 36.8 & \\
\hline$\geq 50$ & 99 & 65.1 & 96 & 63.2 & \\
\hline Menopause & & & & & 0.180 \\
\hline Yes & 45 & 29.6 & 56 & 36.8 & \\
\hline No & 107 & 70.4 & 96 & 63.2 & \\
\hline
\end{tabular}

*Tumor diagnosis based on CBE : clinical breast examination 
half were respondents with low educational level, with BMI $\geq 25$ and TCC $\geq 200 \mathrm{mg} / \mathrm{dL}$. A large proportion in the $\mathrm{CBE}(-)$ group were respondents with triglyceride concentration of $<150 \mathrm{mg} / \mathrm{dL}$, $\mathrm{LDL} \geq 100 \mathrm{mg} / \mathrm{dL}, \mathrm{HDL} \geq 50 \mathrm{mg} / \mathrm{dL}$ and who were not yet in menopause.

Table 2 shows that both in $\operatorname{CBE}(+)$ and CBE(-) groups, a larger proportion were nonsmoking, had no stress, had $\geq 2$ children, with a duration of breastfeeding of $\geq 6$ months, without family history of breast cancer, with consumption of fried foods, milk, coconut milk and packaged beverages of $<3$ times per week. In the $\mathrm{CBE}(+)$ group, it was apparent that the percentage of $\mathrm{HC}$ users was double that of the non-users, while in the CBE(-) group, there were almost no differences between $\mathrm{HC}$ users and non-users.

From the results of multivariate analysis (Table 3), the odds ratio of $\mathrm{HC}$ users was 1.8fold greater ( $\mathrm{aOR}=1.83 ; 95 \% \mathrm{CI}: 1.11-3.04)$ than those of non-users, after controlling for TCC, smoking status, and parity. The odds ratio in the $\mathrm{CBE}(+)$ group in respondents with $\mathrm{TCC}<200 \mathrm{mg} /$ $\mathrm{dL}$ was 1.6 -fold greater $(\mathrm{aOR}=1.62 ; 95 \% \mathrm{CI}$ : 1.01-2.60) those that of the respondents with TCC $\geq 200 \mathrm{mg} / \mathrm{dL}$. The OR of current smoking was 1.01 (95\% CI: 0.52-1.96) and those of former smoking $0.49(\mathrm{aOR}=0.49 ; 95 \% \mathrm{CI}: 0.26-1.93)$, as

Table 2. Risk factors for breast tumors based on positive and negative CBE

\begin{tabular}{|c|c|c|c|c|c|}
\hline \multirow{3}{*}{ Risk factor } & \multicolumn{4}{|c|}{ CBE } & \multirow{3}{*}{ p value } \\
\hline & \multicolumn{2}{|c|}{ Positive } & \multicolumn{2}{|c|}{ Negative } & \\
\hline & $\mathbf{n}$ & $\%$ & $\mathbf{n}$ & $\%$ & \\
\hline Smoking status & & & & & 0.188 \\
\hline Nonsmoking & 109 & 71.7 & 99 & 65.1 & \\
\hline Former smoking & 20 & 13.2 & 32 & 21.1 & \\
\hline Current smoking & 23 & 15.1 & 21 & 13.8 & \\
\hline Stress & & & & & 0.803 \\
\hline No & 107 & 70.4 & 105 & 69.1 & \\
\hline Yes & 45 & 29.6 & 47 & 30.9 & \\
\hline Parity (no. of children) & & & & & 0.728 \\
\hline$\geq 2$ children & 111 & 73.0 & 117 & 77.0 & \\
\hline 1 child & 29 & 19.1 & 25 & 16.4 & \\
\hline without or as yet without a child & 12 & 7.9 & 10 & 6.6 & \\
\hline Duration of breastfeeding & & & & & 0.428 \\
\hline$\geq 6$ months & 126 & 82.9 & 131 & 86.2 & \\
\hline$<6$ months/never & 26 & 17.1 & 21 & 13.8 & \\
\hline Hormonal contraception & & & & & 0.035 \\
\hline No & 51 & 33.6 & 69 & 45.4 & \\
\hline Yes & 101 & 66.4 & 83 & 54.6 & \\
\hline Family history of breast cancer & & & & & 1.000 \\
\hline Absent & 146 & 96.1 & 146 & 96.1 & \\
\hline Present & 6 & 3.9 & 6 & 3.9 & \\
\hline Consumption of fried foods & & & & & 0.398 \\
\hline$<3$ times/week & 103 & 67.8 & 96 & 63.2 & \\
\hline$\geq 3$ times/week & 49 & 32.2 & 56 & 36.8 & \\
\hline Milk consumption & & & & & 0.435 \\
\hline$<3$ times/week & 109 & 71.7 & 115 & 75.7 & \\
\hline$\geq 3$ times/week & 43 & 28.3 & 37 & 24.3 & \\
\hline Coconut milk intake & & & & & 0.523 \\
\hline$<3$ times/week & 112 & 73.7 & 107 & 70.4 & \\
\hline$\geq 3$ times/week & 40 & 26.3 & 45 & 29.6 & \\
\hline Consumption of packaged beverages & & & & & 0.368 \\
\hline$<3$ times/week & 122 & 80.3 & 128 & 84.2 & \\
\hline$\geq 3$ times/week & 30 & 19.7 & 24 & 15.8 & \\
\hline
\end{tabular}

* Tumor diagnosis based on CBE: Clinical breast examination 
Table 3. Multiple logistic regression analysis of risk factors for braest tumors in adult women

\begin{tabular}{|c|c|c|c|c|c|c|}
\hline Risk factor & $\begin{array}{c}\text { Crude } \\
\text { OR } \\
\end{array}$ & $95 \% \mathrm{CI}$ & p & $\begin{array}{c}\text { Adj } \\
\text { OR }\end{array}$ & $95 \% \mathrm{CI}$ & $p$ value \\
\hline \multicolumn{7}{|c|}{ Hormonal contraception } \\
\hline No & 1.00 & Reference & & 1.00 & Reference & \\
\hline Yes & 1.65 & $1.04-2.62$ & 0.035 & 1.83 & $1.11-3.04$ & 0.019 \\
\hline \multicolumn{7}{|l|}{ Total cholesterol } \\
\hline$\geq 200 \mathrm{mg} / \mathrm{dL}$ & 1.00 & Reference & & 1.00 & Reference & \\
\hline$<200 \mathrm{mg} / \mathrm{dL}$ & 1.70 & $1.08-2.68$ & 0.022 & 1.62 & $1.01-2.60$ & 0.044 \\
\hline \multicolumn{7}{|l|}{ Smoking status } \\
\hline Non-smoking & 1.00 & Reference & & 1.00 & Reference & \\
\hline Former smoking & 0.57 & $0.31-1.06$ & 0.074 & 0.49 & $0.26-1.93$ & 0.028 \\
\hline Current smoking & 0.99 & $0.52-1.91$ & 0.987 & 1.01 & $0.52-1.96$ & 0.987 \\
\hline \multicolumn{7}{|c|}{ Parity (no. of children) } \\
\hline$\geq 2$ children & 1.00 & Reference & & 1.00 & Reference & \\
\hline 1 child & 1.22 & $0.68-2.22$ & 0.507 & 1.21 & $0.65-2.25$ & 0.555 \\
\hline None & 1.27 & $0.53-3.05$ & 0.600 & 1.77 & $0.69-4.53$ & 0.234 \\
\hline
\end{tabular}

* Adjusted odds ratio controlled for variables in this table; ** Tumor diagnosis based on CBE

compared with respondents who were nonsmoking, but this difference was statistically not significant. Similarly with parity, although the adjusted odds ratio $(\mathrm{aOR})$ of $\mathrm{CBE}(+)$ respondents was 1.21 (95\% CI: 0.65-2.25) for those who have only one child and 1.77 (95\% CI: $0.69-4.53)$, for those who have no children, was higher than in the respondents with $\geq 2$ children, this result was also not statistically significant. In this connection, smoking status and parity are confounding variables, that if excluded from the multivariate analysis causes changes in OR of $\mathrm{HC}$ (as the principal independent variable) $>10 \%$.

\section{DISCUSSION}

The respondents who used HC had a 1.8fold greater risk for developing breast tumors as compared with those who were non-users. This is according to the study results of Urban et al. ${ }^{(9)}$ who showed an increase in the OR of breast cancer in users of contraceptive pills and/or injections. Poosari et al. ${ }^{(15)}$ found an increased risk of breast cancer of 1.31 times in $\mathrm{HC}$ users, which was however statistically non-significant $(95 \% \mathrm{CI}$ : $0.65-2.65)$.

In general, with regard to $\mathrm{HC}$ composition, the pills contain estrogen and progesterone, whereas the mini pills, injections and implants contain progesterone. ${ }^{(5,6)}$ Artoum et al. ${ }^{(27)}$ state that estrogen contribute to the development of tumors by promoting cell proliferation and mutation or by increasing the probability of mutations that regulate growth and differentiation of mammary cells that may play an important role in the growth of breast cancers. According to Sirait et al., ${ }^{(11)}$ the growth of mammary tissues is very sensitive to estrogen, therefore females with long-term exposure to estrogen will carry a high risk for the occurrence of breast cancer. Breast cancer is characterized by the loss of estrogen receptors (ERs) that is associated with aggressive pathology and a low level of estimated recovery (prognosis). ${ }^{(28)}$

Before the publication of the study results of Women's Health Initiative (WHI) in the US in 2002 , many experts were of the opinion that the increased risk of breast cancer observed in HRT research was due to the effect of estrogen. After the WHI results had found, the focus changed to progesterone, which was considered to increase cell division and accumulation of damaged DNA. The highest proliferative activity occurs in the luteal phase of the menstrual cycle (when the endogenous progesterone concentration is high). ${ }^{(29)}$ Daniel et al. ${ }^{(8)}$ state that progestin added to HRT significantly increases the incidence of breast tumors and the breast tumor stage in females who are in menopause. Therefore progesterone is no longer considered a completely 
safe alternative. According to Lanari, ${ }^{(30)}$ more than $70 \%$ of breast cancers express the estrogen receptor alpha $(\mathrm{ER} \alpha)$ and respond to antiestrogen therapy. These cancers also express progesterone receptors that are reliable markers for estrogen receptors.

The results of research by Llanos et al., ${ }^{(31)}$ Shah et al., ${ }^{(32)}$ Melvin et al. ${ }^{(33)}$ and $\mathrm{Ni}$ et al. ${ }^{(34)}$ showed that higher TCC has a less risk for breast tumors/cancers than lower TCC, therefore in the present further analysis TCC of $\geq 200 \mathrm{mg} / \mathrm{dL}$ (high) is positioned as reference for determining the odds ratio of TCC of $<200 \mathrm{mg} / \mathrm{dL}$ (low). The multivariate results show that TCC $<200 \mathrm{mg} / \mathrm{dL}$ actually increases the risk of breast tumors by 1.6-fold as compared with TCC of $\geq 200 \mathrm{mg} / \mathrm{dL}$. This is in line with the study results of Llanos et al. ${ }^{(31)}$ who state that there is an inverse relation between the risk of breast cancer and TCC ( $\mathrm{OR}=0.46$; 95\% CI: 0.25-0.85), in other words, TCC in the cases was significantly lower (189.3 $\mathrm{mg} / \mathrm{dL}$ ) as compared with the controls (206.8 mg/ dL). Similarly, the study results of Shah et al. ${ }^{(32)}$ found that higher TCC was significantly associated with a decreased risk of breast cancer $(\mathrm{OR}=0.30 ; 95 \%$ CI: 0.12-0.76). While Melvin et al. ${ }^{(33)}$ and $\mathrm{Ni}$ et al. ${ }^{\left({ }^{(3)}\right)}$ found that higher TCC has a lower risk for breast cancer, although results were not statistically significant, i.e. $\mathrm{HR}=0.97(95 \%$ CI: 0.89-1.05) and RR=0.96 (95\% CI: 0.86-1.07), respectively. These results differed with those of a study by Kitahara et al. ${ }^{(35)}$ who state that higher TCC $(\geq 240 \mathrm{mg} / \mathrm{dL})$ is positively associated with breast cancer $(\mathrm{HR}=1.17$; 95\% CI: 1.03-1.33). There are also the results of the study by $\mathrm{Hu}$ et al. ${ }^{(36)}$ who found that higher TCC increases the risk of breast cancer (OR $=1.45$; 95\% CI: 1.14 1.85). Likewise, the study by Peela et al. ${ }^{(37)}$ found significantly increased TCC in patients with breast cancer. Llaverias et al. ${ }^{(38)}$ state that in general the role of cholesterol in the initiation and development of tumors is very controversial. Low cholesterol concentrations are known to be used as a cancer marker, and several types of cancer appear to decrease plasma cholesterol level. This is the result of increased utilization of cholesterol by the tumors for their development. Thus the increased plasma cholesterol level accelerates the development and increases the aggressivity of the tumors. From the results of the study by McDonell et al. ${ }^{(39)}$ it is known that cholesterol does not play a direct role in tumor pathogenesis, but cholesterol or its derivatives function as marker molecule in cancer cells. Cholesterol is the raw material for the biosynthesis of steroid hormones, one of them being estradiol (estrogen). ${ }^{(40,41)}$ According to Llaverias et al. ${ }^{(38)}$ an important aspect that has to be considered when testing the correlation between plasma cholesterol and breast cancer is that the estrogen concentration is also associated with plasma HDL cholesterol.

In the present analysis it was found that the relationship between smoking status and the risk of breast tumors was statistically not significant $(\mathrm{aOR}=0.49)$ for former smoking and $\mathrm{aOR}=1.01$ for current smoking, as compared with nonsmoking. Comparatively identical results were found by Xue et al. ${ }^{(18)}$ in their research the $\mathrm{HR}=1.06$ (95\% CI: 1.01-1.11) for former smoking and $\mathrm{HR}=1.09$ (95\% CI: 1.02-1.17) for current smoking, after controlling for age at menopause, menopause status and use of hormones postmenopause as compared with nonsmoking. Pasarelli et al. ${ }^{(42)}$ even differentiate the risk of smoking between 1 year before and 1 year after diagnosis of breast cancer. Individuals who for 1 year before diagnosis of breast cancer were active smoking, had a 1.3-fold higher risk of dying from breast cancer (HR=1.25; 95\% CI: 1.13-1.37) as compared with nonsmoking. While $10 \%$ of females who continued to smoke after diagnosis, had a 1.7-fold higher risk of dying from breast cancer $(\mathrm{HR}=1.72 ; 95 \% \mathrm{CI}: 1.13-2.60)$, as compared with nonsmoking. According to Bjerkaas et al., ${ }^{(43)}$ several large prospective cohort studies have found that smoking can cause breast cancer, especially in females who smoke for an extended period of time, those who smoke a great number of cigarettes per day and those who smoke before delivering their first child. Their research results showed that the mortality from breast cancer may indeed be low, but increases 
significantly for active smoking (current) and former smoking (HR=1.15; 95\% CI: 1.01-1.32 and $\mathrm{HR}=1.15 ; 95 \% \mathrm{CI}: 1.02-1.30$, respectively), as compared with nonsmoking. Based on the study by Bishop et al. ${ }^{(44)}$ it is known that the relative mortality risk from breast cancer is 1.44 for current smoking (95\% CI: 1.01-2.06) and 1.13 for former smoking (95\% CI: 0.66-1.94), as compared with nonsmoking.

In the present study it was found that respondents with 1 child had an $\mathrm{aOR}=1.21$ and that respondents who have no children, had an $\mathrm{aOR}=1.77$, which is greater than in respondents who have $\geq 2$ children. However, these results were statistically not significant, Sirait et al. ${ }^{(11)}$ found that persons who have no children have a 1.97fold greater risk (95\% CI: 1.24-3.14) and that those who have 1 child have a 1.64 -fold greater risk (95\% CI: 1.16-2.33) that is statiscally significant as compared with persons who have 4 children. With reference to the statement of Shen et al., ${ }^{(45)}$ in that increased parity (the number of deliveries) is a protective factor against breast cancer, because parity decreases estrogen/ progesterone receptor-positive breast cancers and breastfeeding (lactation) decreases the risk of receptor positive or negative breast cancers or both. Heys et al. ${ }^{(46)}$ state that estrogen increases during pregnancy then decreases post-delivery until around 1 year. Futhermore, breastfeeding temporarily decreases estrogen post-delivery. The concentration of estrogen during the ovulatory cycle is lower after the first pregnancy when compared with females who have never borne any children. This differs from the results of the study by Sun et al. ${ }^{(20)}$ who showed that subjects who had 1-2 children had a 1.32-fold greater risk of suffering from breast cancer (95\% CI: 0.89-1.95), while subjects who had $\geq 3$ children had a 1.77 fold greater risk of suffering from breast cancer (95\% CI: 1.18-2.66) as compared with subjects who had never borne any children.

Thus it can be explained that the exogenous steroid hormones (estrogen/progesterone) contained in $\mathrm{HC}$ promote tumor cell proliferation and accumulate DNA damage. ${ }^{(29)}$ Low cholesterol concentrations are known to be able to become cancer markers. This is caused by the increased utilization of cholesterol by the tumors for their development. The increased concentrations of plasma cholesterol, which is the raw material for the biosynthesis of steroid hormones, accelerates the development and increases the aggressivity of tumors. ${ }^{(38)}$ In addition, the substances contained in cigarettes, such as nitrosamine and nicotine, can also be carcinogenic. Nitrosamine induces cancers by causing gene and/or DNA mutations, while nicotine promotes cancer cell development. ${ }^{(47)}$ Meanwhile, parity (the total number of children) is a measure of a life-long exposure to endogenous steroid hormones (from pregnancy and delivery up to the lactation period). Exposure to high concentrations of exogenous or endogenous steroid hormones is associated with the risk of breast cancer. ${ }^{(29)}$

The limitations of the present study are as follows. First, there are no data on the total number of cigarettes smoked per week by the occasional smoking; second, there is no separate question for respondents who use one type of $\mathrm{HC}$ and for those who use more than one type of $\mathrm{HC}$ (combined HC) and for duration of use; third, there is no question about whether or not $\mathrm{HC}$ was used continuously; and fourth for respondents who had ever used $\mathrm{HC}$, there is no question about the duration of cessation of $\mathrm{HC}$ use, because according to the study results of Cibula et al., ${ }^{(48)}$ the effect of $\mathrm{HC}$ (pills) on the risk of breast cancer will disappear after cessation of the use of the contraceptive pills for 5-10 years. It is recommended that future studies, especially about questions on the type and duration of HC use may be more focused, so that the results will be increasingly improved.

\section{CONCLUSION}

Hormonal contraceptive (HC) users had a 1.8-fold increased risk of breast tumors after controlling for TCC $(\geq 200 \mathrm{mg} / \mathrm{dL}=$ reference $)$, smoking status and parity $(\geq 2$ children $=$ reference). 


\section{CONFLICT OF INTEREST}

The author declare that there is no conflict interest in this article.

\section{ACKNOWLEDGEMENT}

The authors wish to extend their utmost gratitude to dr. Iwan Ariawan (FKM-UI), Dr. Ekowati Rahajeng, SKM, M.Kes and dr. Delima, M.Kes (Badan Penelitian dan Pengembangan Kesehatan) who provided guidance and direction, from the data analysis up to the preparation of the manuscript.

\section{CONTRIBUTORS}

ST contributed to the literature search, data analysis and writing of the draft. ANS contributed to "data cleaning" before data analysis (particularly that associated with CBE) and literature search. All authors read and approved the final manuscript.

\section{REFERENCES}

1. Jemal A, Bray F, Center MM, et al. Global cancer statistics. CA Cancer J Clin 2011;61:69-90. doi: 10.3322/caac. 20107.

2. International Agency for Research on Cancer World Health Organization. Global cancer burden rises to 14.1 million new cases in 2012: marked increase in breast cancers must be addressed. Lyon, France: International Agency for Research on Cancer;2013.

3. Wahidin M. Deteksi dini kanker leher rahim dan kanker payudara di Indonesia 2007-2014. Buletin Jendela Data Informasi 2015;Semester I:12-5.

4. Anderson KN, Schwab RB, Martinez ME. Reproductive risk factors and breast cancer subtypes: a review of the literature. Breast Cancer Res Treat 2014;144:1-10. doi: 10.1007/s10549-0142852-7.

5. Zahra Z, Khairun N. Analisis hubungan penggunaan kontrasepsi hormonal dengan disfungsi seksual pada wanita. Majority 2015;4: 103-8.

6. Sety LM. Jenis pemakaian kontrasepsi hormonal dan gangguan menstruasi di wilayah kerja Puskesmas. J Kesehatan 2014;5:60-6.
7. Yue W, Wang JP, Li Y, et al. Effects of estrogen on breast cancer development: role of estrogen receptor independent mechanisms. Int J Cancer 2010;127:1748-57. doi: 10.1002/ijc.25207.

8. Daniel AR, Hagan CR, Lange CA. Progesterone receptor action: defining a role in breast cancer. Expert Rev Endocrinol Metab 2011;6:359-69. doi:10.1586/eem.11.25.

9. Urban M, Banks E, Egger S, et al. Injectable and oral contraceptive use and cancers of the breast, cervix, ovary, and endometrium in Black South African Women: case-control study. PLoS Med 2012;9:e1001182. doi: 10.1371/journal.p med. 1001182.

10. Sihombing M, Sapardin AN. Faktor risiko tumor payudara pada perempuan umur 25-65 tahun di lima Kelurahan di Kecamatan Bogor Tengah. J Kesehatan Reproduksi 2014;5:175-84.

11. Sirait AM, Ratih O, Lely I. Hubungan kontrasepsi pil dengan tumor/kanker payudara di Indonesia. Maj Kedokt Indon 2009;59:348-56.

12. Zafar A. Clinical breast examination: the diagnostic accuracy in palpable breast lumps. Prof Med J 2014;21:1147-52.

13. Ravi C, Rodriguez G. Accuracy of clinical examination of breast lumps in detecting malignancy: retrospective study. Indian J Surg Oncol 2012;3:154-7. doi: 10.1007/s13193-012-01515.

14. Khoda L, Kapa B, Singh KG, et al. Evaluation of modified triple test (clinical breast examination, ultrasonography, and fine-needle aspiration cytology) in the diagnosis of palpable breast lumps. J Med Soc 2015;29:26-30.

15. Poosari A, Promthet S, Kamsaard S, Suwanrungruang K, Longkul J, Wiangnon S. Hormonal contraceptive use and breast cancer in Thai women. J Epidemiol 2014;24:216-20. doi: 10.2188/jea.JE20130121.

16. Sastroasmoro S, Ismael S. Dasar-dasar metodologi penelitian klinis. Edisi ke-5. CV. Sagung Seto Jakarta. 2014.

17. Badan Penelitian dan Pengembangan Kesehatan. Laporan studi kohor faktor risiko penyakit tidak menular (PTM). Jakarta;2012.

18. Xue F, Willett WC, Rosner BA, et al. Cigarette smoking and the incidence of breast cancer. Arch Intern Med 2011;171125-33. doi: 10.1001/ archinternmed.2010.503.

19. Scholte WF, Verduin F, van Lammeren A, et al. Psychometric properties and longitudinal validation of the self-reporting questionnaire (SRQ-20) in a Rwandan community setting: a validation study. BMC Med Res Method 2011;11:116. doi: 10.1186/1471-2288-11-116. 
20. Sun X, Nichols HB, Tse CK, et al. Association of parity and time since last birth with breast cancer prognosis by intrinsic subtype. Epidemiol Biomarkers Prev 2015;251:60-7. doi: 10.1158/10559965.EPI-15-0864.

21. Ambrosone CB, Zirpoli G, Ruszczyk M, et al. Parity and breastfeeding among African-American women: differential effects on breast cancer risk by estrogen receptor status in the Women's Circle of Health Study. Cancer Causes Control 2014;25:259-65. doi: 10.1007/s10552-013-0323-9.

22. Sulistyowati T, Sihombing M. Frequent coconut milk intake increases the risk of vascular disease in adults. Univ Med 2015;34:149-58. doi: 10.18051/ Univmed.2015.v34.149-158.

23. Gray LJ, Yates T, Davies MJ, et al. Defining obesity cut-off points for migrant South Asians. PLoS ONE 2011;6:e26464. doi: 10.1371/journal.pone. 0026464.

24. Misra A, Shrivastava U. Obesity and dyslipidemia in South Asians. Nutrients 2013;5:2708-33. doi: 10.3390/nu5072708.

25. Jacobson TA, Ito MK, Maki KC, et al. National lipid association recommendation for patientcentered management of dyslipidemia: Part 1-Full Report. Journal J Clin Lipidol 2015;9:129-69. doi: 10.1016/j.jacl.2015.02.003.

26. Hastono SP. Analisis data. Jakarta: FKM UI; 2006.

27. Artoum M, Al Hourani H, Nimer N, et al. Endogenous estradiol, estrogen and progesterone receptors increase benign and breast cancer risk among non-familial postmenopausal females. Health Sci J 2012;6:693-702.

28. Palmer JR, Viscidi E, Troester MA, et al. Parity, lactation, and breast cancer subtypes in African American women: results from the AMBER consortium. J Natl Cancer Inst 2014;106:1-8. doi: 10.1093/jnci/dju237.

29. Chen WY. Exogenous and endogenous hormones and breast cancer. Best Pract Res Clin Endocrinol Metab 2008;22:573-85. doi: 10.1016/j.beem.2008. 08.001 .

30. Lanari C, Wargon V, Rojas P, et al. Antiprogestins in breast cancer treatment: are we ready? Endocr Relat Cancer 2012;19:R35-50. doi: 10.1530/ERC-110378.

31. Llanos AA, Makambi KH, Tucker CA, et al. Cholesterol, lipoprotein, and breast cancer risk in African American women. Ethn Dis 2012; 22:2817.

32. Shah FD, Shukla SN, Shah PM, et al. Significance of alterations in plasma lipid profiles levels in breast cancer. Intregr Cancer Ther 2008;7:33-41.

33. Melvin JC, Seth D, Holmberg L, et al. Lipid profiles and risk of breast and ovarian cancer in the
Swedish AMORIS Study. Cancer Epidemiol Biomarkers Prev2012;21:1381-4. doi: 10.1158/10559965.

34. Ni H, Liu H, Gao R. Serum lipids and breast cancer risk: a meta-analysis of prospective cohort studies. PloS ONE 2015;10:1-15. e0142669. doi: 10.1371/journal.pone.0142669.

35. Kitahara CM, de González AB, Freedman ND, et al. Total cholesterol and cancer risk in large prospective study in Korea. J Clin Oncol 2011; 29:1592-8. doi: 10.1200/JCO.2010.31.5200.

36. $\mathrm{Hu}$ J, La Vecchia C, de Groh M, et al. Dietary cholesterol intake and cancer. Ann Oncol 2012;23:491-500. doi: 10.1093/annonc/mdr 155.

37. Peela JR, Jarari AM, El Saiety SO, et al. The relationship between serum lipids and breast cancer in Libya. Biochem Anal Biochem 2012;1: 1-3. doi: 10.4172/2161-1009.1000117.

38. Llaverias G, Danilo C, Mercier I, et al. Role of cholesterol in the development and progression of breast cancer. Am J Pathol 2011;178:402-12. doi: 10.1016/j.ajpath.2010.11.005.

39. McDonell D, Chang CY, Nelson ER. The estrogen receptor as a mediator of the pathological action of cholesterol in breast cancer. Climacteric 2014;17:60-5. doi: 10.3109/13697137.2014.966949

40. Kumar V, Singh A, Sidhu DS, et al. A comparative study to evaluate the role of serum lipid levels in aetiology of carcinoma breast. J Clin Diag Res 2015;9:PC01-PC3. doi: 10.7860/JCDR/2015/ 12273.5563.

41. Hu J, Zhang Z, Shen WJ, et al. Cellular cholesterol delivery, intracellular processing and utilization for biosynthesis of steroid hormones. Nutri Metab 2010;7:47. doi: 10.1186/1743-7075 -7-47.

42. Pasarelli MN, Newcomb PA, Hampton JM, et al. Cigarette smoking before and after breast cancer diagnosis: Mortality from breast cancer and smoking-related diseases. J Clin Oncol 2016;34:1315-22. doi: 10.1200/JCO.2015.63.9328.

43. Bjerkaas E, Parajuli R, Engeland A, et al. The association between lifetime smoking exposure and breast cancer mortality - results from a Norwegian cohort. Cancer Med 2014:1-10. doi: 10.1002/cam4.304.

44. Bishop JD, Killelea BK, Chagpar AB, et al. Smoking and breast cancer recurrence after breast conservation therapy. Int J Breast Cancer 2014, Article ID 327081, 5 pages. http://dx.doi. org/ $10.1155 / 2014 / 327081$

45. Shen S, Zhong S, Xiao G, et al. Parity association with clinicopathological factors in invasive breast cancer: a retrospective analysis. Onco Targets Ther 2017;10:477-81. http://dx.doi.org/10.2147/ OTT.S123888. 
46. Heys M, Jiang C, Cheng KK, et al. Life long endogenous estrogen exposure and later adulthood cognitive function in a population of naturally postmenopausal women from Southern China: the Guangzhou Biobank cohort study. Psychoneuroendocrinology 2011;36:864-73. doi: 10.1016/j.psyneuen.2010.11.009.
47. Xue J, Yang S, Seng S. Mechanisms of cancer induction by tobacco-specific NNK and NNN. Cancers 2014;6:1138-56. doi: 10.3390/cancers 6021138.

48. Cibula D, Gompel A, Mueck AO, et al. Hormonal contraception and risk of cancer. Hum Reprod Update 2010;16:631-51. 